\title{
Relationship between Instructional Supervisory Practices by Principals and Academic Performance in Public Secondary Schools in Nakuru Municipality, Kenya
}

\author{
Flora Kemunto Ontiriah Marwanga, \\ Adjunct lecturer, Kenyatta University, University of Nairobi, College of Education, and African Nazarene \\ University, P.O BOX 339 KNH 00202 NAIROBI
}

\begin{abstract}
Institutional supervision is a component of general supervision . This is one of the activities that educational supervisors are supposed to carry out in teaching and learning. Its' primary function is to improve instruction and its' outcomes. It is aimed at enhancing teaching and learning. Principals in secondary schools are the immediate supervisors in the schools that they head. The aim of this research was to investigate instructional supervisory practices used by School Principals in Nakuru Municipality, Nakuru County, Kenya. It sought to find out the academic and professional qualifications and training of such supervisors, the extent of their involvement in carrying out supervisory activities, adequacy, frequency and methods of carrying out clinical supervision, attendance of in-service courses and the relationship between instructional supervision and performance of public Secondary schools in national examinations. The study employed an ex-post factor design targeting a population of nineteen Principals in public Secondary schools in Nakuru Municipality. Purposive sampling was used to get the respondents. A questionnaire with three sections of personal data, professional training, preparation, supervisory activities carried out and effect of those activities on performance in national examinations was used to collect data. The findings established that majority of principals in public Secondary schools were male, most of them had inadequate professional training, were ill prepared for clinical supervision hence handled it poorly and inadequately. In-service courses offered were inadequate of poor quality and that instructional supervision did not have a significant influence on schools' performance in national examinations. The study recommended that more females be appointed as Principals ,the Principals be given specific professional training and preparation before appointment to the position of Principalship, in-service courses be more frequent, and relevant topics covered to equip Principals with knowledge and skills on instructional supervision and that instructional supervision ought to be restructured and be more frequent so as to positively influence performance of public Secondary in national examinations .
\end{abstract}

Key words: Instructional supervision, Supervisor /Inspector, Principal, Secondary school, Performance

\section{Background to the study}

The history of supervision in Kenya dates back to 1910 when the colonial government appointed the first Director of education for the protectorate. Among others the legal duties of the director of education were organization of supervisor and inspection of protectorate schools. In 1924, the first education ordinance was passed which required that all schools be registered and open doors to inspection by the Director of education. The Beecher Report of 1949, among other things recommended the introduction of efficient supervision and inspection .Instructional supervision is a component of general supervision that a Principal is involved in within a school .Its' primary function is the improvement of instruction. The Inspector's functions can be listed as being giving direction ,combating routine and encouraging good initiatives, improvement of teacher's professional status ,the adoption and diffusion of better techniques and the meaning of progressive programmes of action (Sifuna 1985).

According to Olembo (1975. P.82) functions of school supervision are as follows:

a) Working closely with teachers to establish the problems and needs of students.

b) Building strong group morale and securing effective teamwork among teachers.

c) Providing assistance to teachers so as develop greater competence in teaching.

d) Assisting newly posted teachers to translate theories into classroom practices.

e) Working with teachers to identify and analyze learning difficulties of students and helping in planning effective remedial Instructions.

f) Evaluating teaching effectiveness in terms of student growth and educational objectives.

g) Providing guidance and advisory services related to curriculum Innovations. 
Although supervisor's roles are well articulated, their performance is far from adequate. The blame is placed on a number of issues/factors. This include, lack of adequate and close supervision, sufficient number of supervisors, poor supervisory skills and techniques which could be related to lack of training supervisors as professionals hence poor techniques of carrying out their work. One of the transformations called for in education and does not receive the attention it deserves are the changing roles of the school Principal. They have to continue and remain representatives of public authority with power in many cases over the professional lives of teachers and at the same time act as leaders, guide philosophers, advisors, supporters, mentors and friends of both teachers and students .Many Principals doubtedly feel the dilemma keenly. Formerly, emphasis of Inspector's work was of authoritarian control, prescription and enforcement. Today it is persuasive, leadership, consultation and guidance. However, supervision in schools shows an implicit but fully functioning superior subordinate relationship generated by Institutional hierarchies. This relationship is considered counterproductive in supervision (Ominde, 1964) . The manner in which inspectors duties are carried out in practice both as regards efficiency of procedures used and the kind of relationship built with teachers is of great importance. The outcome of this supervision is therefore of special interest and worth investigating. The immediate supervisor in a school is the Principal. This is fully supported by the Teachers service commission (TSC.P2) code of regulations which spells this out when it states that 'A teacher shall be required to obey directions given by the commission, its agents the Headmaster/Principal, a person appointed in accordance with the Education Act (CAP 212) Section 18(1), or any other person under whose supervision he is placed'. Kenya has gone through major educational restructuring since independence and more so in the last twenty years. This has big implications for Secondary Principals as instructional supervisors .Increase in student enrollment has created challenges such as lack of adequate learning resources and physical facilities. These challenges have in turn resulted in other problems such as management of available learning resources and poor quality instruction. Under these conditions, the importance of supervision as a means of improving school instruction has gained more emphasis more than ever before. Supervision of instruction is one of the major functions of a school Principal (Chiemcla 1982.p.3) Supervision has been identified as a major cause of low educational standards in Kenya. Strengthening of supervision by school Principals is therefore indispensable. The study therefore sought to investigate instructional supervisory practices used by School Principals and their effect on academic performance in national examinations in Nakuru Municipality, Nakuru County, Kenya.

\section{Statement of the problem.}

The Inspectorate Department of the Ministry of Education, Science and Technology (MoEST) is headed by the Director of educational standards in the County. The Chief Inspector of Schools is responsible for all inspections done in public learning institutions. To achieve this objective , the department arranges for constant visitations to schools to check on administration, teaching and learning facilities and actual classroom instruction by teachers. However, by and large, the Principals who are the immediate supervisors of schools are expected conduct such supervision more frequently and keenly. This is because they work more closely with the teachers. In carrying out this, Principals have been accused of being autocratic and fault finders. This behavior stifles the creative spirit of the teachers who are dedicated to self improvement in the teaching and learning process. They still control and direct teachers, unaware of the consultative, analytical and diagnostic functions of supervision. Research into the challenges that Principals experience and the manner in which they provide their advice support, help, leadership, expert knowledge and guidance to teachers in analyzing and diagnosing their teaching behavior for improvement of instruction needs to be analyzed. The role of the Principal in instructional supervision in influencing teachers to carry out their instructional tasks well in line with the objectives stipulated in the curriculum is crucial. Complaints from education stakeholders, politicians, parents and the general public in respect to the quality of teaching and learning in public secondary schools has made the Principal's role in supervision be looked into more keenly. The blame for mass failure of students in Kenya Certificate of Secondary Education (KCSE) is invariably placed on teachers in general and Principals in particular. Constraints to effective secondary school instructional supervision, which hinder better performance, needs to be mapped out. Success of a school, teachers and its' Principal is judged by how well it performs in national examinations. Therefore, it is essential that an instructional supervision criterion to help Principals ensure that quality teaching and learning goes on well is established. The aim of this study was to investigate instructional supervisory practices used by School Principals and their effect on performance in national examinations in Nakuru Municipality, Nakuru County, Kenya.

\section{Objective of the study}

To determine the influence of instructional supervisory practices on performance of public secondary schools in national examinations.

\section{Methodology}


This study adopted an ex-post factor design .It was carried out in random selected public secondary schools in Nakuru municipality. An accessible population of thirty three public secondary schools took part in the study. A sample size of twenty principals in twenty public Secondary schools was obtained through random sampling .Data was collected using a questionnaire adapted from Chiemala (1982) .The questions were simplified and modified to suit the study .Data collected was edited, classified, categorized and transferred to a computer sheet. Linear regression was used to test the hypothesis using 0.5 level of significances. The statistical package for social sciences (SPSS) provided the formula necessary which allowed hypothesis testing.

\section{Results}

This study tested the hypothesis that stated that,' there is a significant relationship between instructional supervision and performance of public secondary schools in national examinations.

\section{Hypothesis testing}

To determine whether a significant relationship existed between instructional supervision and performance of secondary schools in national examinations, hypothesis $\left(\mathrm{H}_{\mathrm{I}}\right)$ was tested. The hypothesis postulated stated that: There is a significant relationship between supervision and performance of public secondary school.

To test hypothesis, performance and instructional supervisory indices for schools for this research were generated as shown in table $1.1,1.2$ and figure 1.1

Table 1.1 Performance index for secondary schools in Nakuru Municipality in national examinations in 2003.

\begin{tabular}{|c|c|c|}
\hline SCHOOL & $\begin{array}{l}\text { PERFORMANCE } \\
\text { INDEX }\end{array}$ & $\begin{array}{l}\text { SUPERVISORY } \\
\text { INDEX }\end{array}$ \\
\hline Nakuru High School & 0.63 & 0.50 \\
\hline Menengai High School & 0.63 & 0.40 \\
\hline Afraha High School & 0.30 & 0.52 \\
\hline Upper Hill Secondary School & 0.34 & 0.52 \\
\hline Lanet Secondary School & 0.40 & 0.43 \\
\hline Nakuru Central & 0.36 & 0.37 \\
\hline Nakuru Day Secondary & 0.53 & 0.38 \\
\hline Flamingo Secondary & 0.45 & 0.32 \\
\hline Uhuru Secondary & 0.42 & 0.32 \\
\hline Kenyatta Secondary & 0.45 & 0.42 \\
\hline Crater View Secondary & 0.39 & 0.37 \\
\hline Langalanga Secondary & 0.51 & 0.40 \\
\hline Nakuru West Secondary & 0.31 & 0.41 \\
\hline Moi Forces Secondary & 0.67 & 0.42 \\
\hline
\end{tabular}

P1= Mean Score

12

The supervisory index is generated by aggregating of the scores from the supervisors' responses on the questionnaire items on the extent to which they are involved in carrying out supervisory activities. The total scores amount to 53.Each schools' total score is divided by 53 to get a supervisory index ranging between $0-1$ on a continuum.

Table 1.2 Supervisory index for public secondary schools in Nakuru municipality

\begin{tabular}{lcc}
\hline School & supervisory Score & Supervisory Index \\
\hline 1.Nakuru High & 26.5 & 0.50 \\
2.Menengai High & 21.2 & 0.40 \\
3.Afraha secondary & 27.5 & 0.52 \\
4.Upper hill secondary & 27.5 & 0.52 \\
5.Lanet secondary & 22.7 & 0.47 \\
6.Nakuru central secondary & 19.6 & 0.37 \\
7.Nakuru day secondary & 20.1 & 0.38 \\
8.Flamingo secondary & 19.6 & 0.37 \\
9.Uhuru secondary & 20.1 & 0.32 \\
10.Kenyatta secondary & 19.6 & 0.42 \\
11.Crater View secondary & 16.9 & 0.37 \\
12.Langalanga Secondary & 21.2 & 0.40 \\
\hline
\end{tabular}


13. Nakuru West secondary

14.Moi forces secondary
21.7

22.2
0.41

0.42

$\mathrm{SI}=\underline{\text { Supervisory score }}$

53

\section{Figure 1.1: Scatter plot showing relationship of school supervision against school performance}

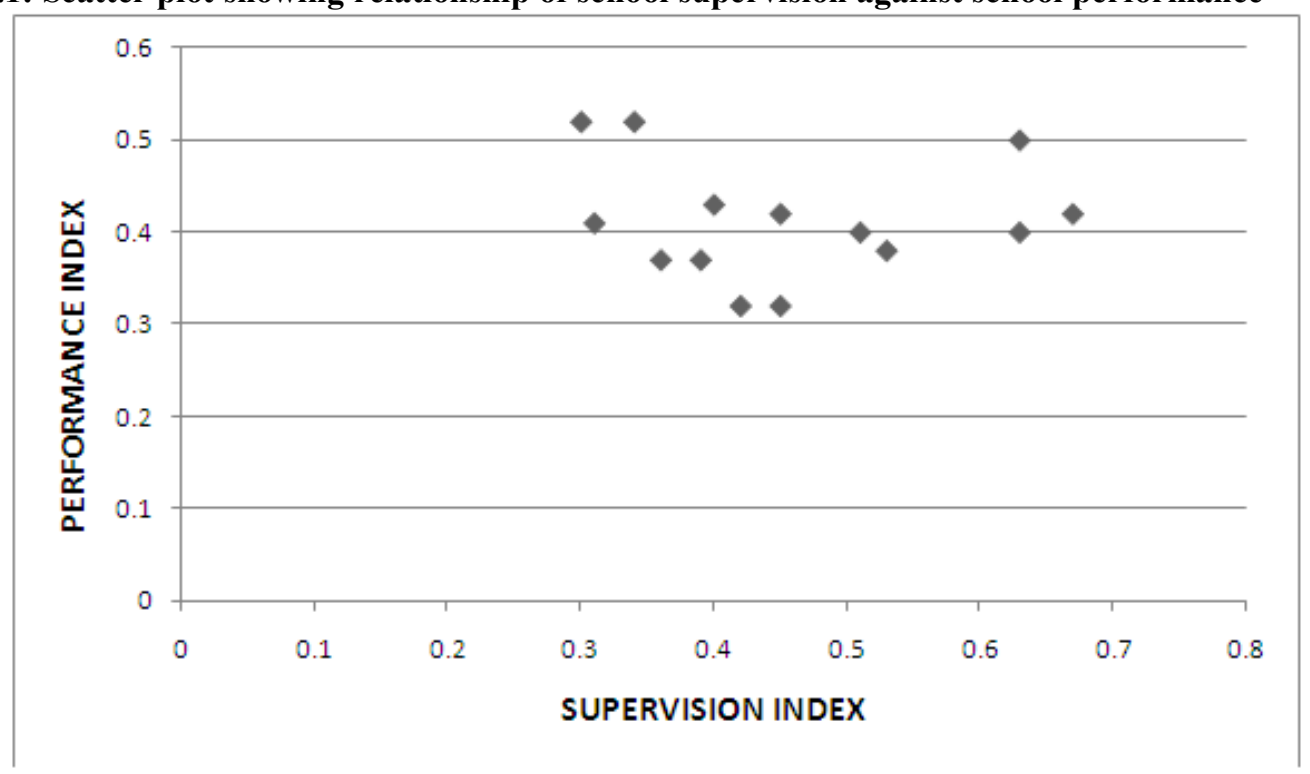

At a glance, the scatter graph did not indicate a clear relationship between instructional supervision and performance of schools in national examinations. The coefficient of correlation is $r=0.043$ at 0.05 significance level. This confirms that the relationship between the two variables is actually minimal. The coefficient of determinants $\mathrm{R}^{2}=0.002$. This is very low and implies that only $0.2 \%$ of the variation in performance can be explained by change in supervision. The remaining $99.98 \%$ of the variations in performance are explained by other factors other than supervision. Consequently, it can be concluded that supervision does not influence performance. Therefore, the directional hypothesis $\left(\mathrm{H}_{1}\right)$ is rejected.

\section{Conclusion}

It was concluded that, educational and professional qualifications do not affect the effectiveness of school Principals. All Principals in public secondary in Nakuru municipality were not well qualified to fit in well in their job descriptions .Instructional supervisory activities were poorly carried out in public secondary schools in Nakuru municipality. In-service courses offered were not adequate, relevant topics not covered and time allocated not enough. Supervisors used poor instructional supervision methods thus instructional supervision has no significant influence on school performance in national examinations .

\section{Recommendations}

Based on the findings of the study, it was recommended that school supervision ought to be more frequent and Principals be more involved .Principals to make a programme with a checklist on how and when to carry out instructional supervision for effectiveness. More, frequent and relevant in-service courses for Principals to be carried out to make them well equipped for their work. Principals to create a condusive partnership relationship with teachers by providing leadership as colleagues for clinical supervision to be effective .This will help them work together as a team aiming at improving educational standards in public secondary schools.

\section{Bibliography}

[1]. Ben, M. (1954). School Inspection and Supervision. National Foundation of Educational Research in England and Wales. Education Abstract. Vol.8.No.5.UNESCO.

[2]. Ben. R., Harris W, (1975). Supervisory Behavior in Education $2^{\text {nd }}$ Edition. Englewood Cliff,New Jersey prentice-Hall.

[3]. Chiemela, N.I. (1982). Instructional Supervisory practices of Anambara state Secondary School Principals. A comparison with desired instructional supervisory practices. Unpublished project. University of Alberta Canada.

[4]. Dull, W.I. (1981). Supervision and School Leadership Handbook. Ohio, Charles E. Merrill publication co.

[5]. Eye, G.G. and Nester, .L.A (1965). Supervision of Instruction. New York, American Book Company. 
[6]. Harrison, H.R. (1968). Supervisory Leadership Education New York: American Book Company.

[7]. Kathyrin V.F., Fiorino A.J., Nowak A.T. (1970). Supervision and curriculum Renewal: A Systems Approach. New york, Meredith Corporation.

[8]. Mugiri , E.M. (1984). Curriculum administration and Supervision. A seminar paper for primary school heads at Kenya Education staff Institute Nairobi

[9]. Njoora E.W. (1988). An investigation into instructional supervisory practices used by head teachers in the northern division of Nairobi province. Unpublished MED. Thesis Kenyatta University.

[10]. Olembo, J.O. (1977). Major functions of school supervisors. A paper presented at an Education Forum Nairobi.

[11]. Raju. B, (1991). The head teacher as an educational leader. The Kenya teachers No.112. Nairobi. Eleza publishers of KNUT.

[12]. Republic of Kenya-Government printer (1964). The Education Commission (Ominde Report) Nairobi. Republic of KenyaGovernment printer (1968) Education Act.

[13]. Wanga, P.E. (1984). Supervision and Instruction: Emerging concepts: Supervision and evaluation. A class handout Kenyatta University.

[14]. Williams, W.S. (1972).New dimensions in supervision. New York, International Text Book Co. 